\title{
Estimation the Presence of Heavy Metals and Trace Elements in Indian Herbal Cosmetics by Atomic Absorption Spectrophotometer
}

\section{Chakraborty Krishnasis *, Choudhary Suraj}

Department of Quality Assurance Al-Ameen College of Pharmacy, Opposite to Lalbagh Main Gate, Hosur road, Bangalore, India

\begin{abstract}
A B S T R A C T
Heavy metals are identically $\mathrm{Pb}, \mathrm{Cd}$ and micronutrients elements like $\mathrm{Ca}, \mathrm{Mg}, \mathrm{Al}, \mathrm{Cu}$ and $\mathrm{Zn}$ were quantitatively estimated using Flame Atomic Absorption Spectrometry (FAAS). Similarly, heavy metals such as As and $\mathrm{Hg}$ were quantitatively estimated by Hydride Generation Technique i.e. Cold Vapor Atomic Absorption Spectrometry method expending nitrogen as carrier gas in 30 herbal cosmetic preparations available in Indian markets. The results designate that among the toxic heavy metals. In the present study, Arsenic was found significantly well below the permissible limit, but Cd was found above the permissible limit in the all samples. Trace elements like $\mathrm{Ca}$ and $\mathrm{Mg}$ were found in higher amount than compare to $\mathrm{Al}, \mathrm{Cu}$, and $\mathrm{Zn}$. Presence of trace elements can corroborate to be beneficial but existence of toxic heavy metals in such amounts certainly has adverse effects on the consumer health who always take the herbal products in an impression of being safe because of the natural origin. In conclusion, execution of strict and isolated regulatory guidelines and promotion of Good Analytical Practice (GAP), Good Manufacturing Practices (GMP) and Good Agricultural and Control Practices (GACP) is suggested for herbal cosmetics by WHO and other regulatory agencies. This study presents the status of heavy metals and trace elements in marketed herbal cosmetic formulations and provides a simple and convenient AAS method which can effectively be adopted at Industrial level for the quality control and standardization of herbal cosmetic preparations and other related products.
\end{abstract}

Keywords: Herbal Cosmetics, WHO, GMP, AAS, Trace elements, Heavy Metals.

A R T I C L E I N F O: Received 08 June 2019; $\quad$ Review Completed 25 July 2019; $\quad$ Accepted 28 Sept. 2019; Available online 15 Oct.. 2019
Cite this article as:
Chakraborty K, Choudhary S, Estimation the Presence of Heavy Metals and Trace Elements in Indian Herbal Cosmetics by
Atomic Absorption Spectrophotometer, Asian Journal of Pharmaceutical Research and Development. 2019; 7(5):60-65,
DOI: http://dx.doi.org/10.22270/ajprd.v7i5.556

\section{INTRODUCTION}

$\mathrm{H}$ erbal medicines have been recognised and have been used from years throughout the world by physicians and patients due to their potential therapeutic effect and their fewer side effects. ${ }^{1-2}$ These preparations are the most treasured products consist of natural components which are used for personal used, called as head to heal. Herbal cosmetics are the valuable products contain the high rich of active constituents of plants active ingredients which enrich the skin with trace (nutrient) elements and other useful minerals, prevent from infection and hence responsible for their cosmetic effects. Even though the herbal preparations are safe, but some of herbal preparations cause serious poisoning and toxic effect due to the preparation containing dangerous toxic drugs or heavy metals. World Health Organization (WHO) and other health organizations currently encourage, recommended and promote traditional herbal preparation in National Health Programs because such drugs are easily available at low cost and are comparatively safe.

According to the WHO, heavy metals concentration of herbal preparation must be controlled. In this case Health Canada

$$
\text { CODEN (USA): AJPRHS }
$$


has taken the initiative and implemented a few measures to control heavy metals concentration and acceptable determined limits i.e. Lead 10ppm, Arsenic 3ppm, Mercury 3 ppm, Cadmium $3 \mathrm{ppm}$, Antimony $5 \mathrm{ppm}$. In the present study, 9 elements, $\mathrm{As}, \mathrm{Hg}, \mathrm{Cd}, \mathrm{Pb}, \mathrm{Cu}, \mathrm{Al}, \mathrm{Zn}, \mathrm{Ca}$ and Mgwere estimated quantitatively in 30 herbal cosmetic preparation available in India by Flame and hydride generation atomic absorption spectroscopy followed by recovery studies as per ICH guidelines. ${ }^{3}$

\section{MATERIAL AND METHOD}

Instrument- Atomic absorption spectroscopy (EC Electronics Corporation of India Limited AAS Element AS AAS-4141) equipped with a deuterium lamp for background correction was used for determination of trace elements and heavy metals.

Sample- 30 samples of marketed herbal preparations were collected. The brand names were given the codes serially. The details are given in Table- 1

Table No. 01: Herbal Cosmetic Product formulation(s) and detail(s):

\begin{tabular}{|c|c|c|c|}
\hline SL No & Composition of Formulations & Uses of the formulation & $\begin{array}{l}\text { Sample } \\
\text { code }\end{array}$ \\
\hline $\mathbf{1}$ & Prunus aemrniaca, Glycyrrhiza glabra, Avena sativa. & Remove dark spots and blemishes. & 1.0 \\
\hline 2 & Aloe barbadensis. & Useful in skin darkness and dryness & 2.0 \\
\hline 3 & Ocimum sanctum & Antiseptic, Antifungal, Cleansing pores. & 3.0 \\
\hline 4 & Carica papaya & Heals damages skin, Control oil of skin & 4.0 \\
\hline 5 & Flagariavesca & Remove skin dead cells and impurities. & 5.0 \\
\hline 6 & Rosa, Trigonellafoenum graecum, Santalum album & $\begin{array}{l}\text { Improve the complexion, Skin pore cleansing and } \\
\text { revitalizing. }\end{array}$ & 6.0 \\
\hline 7 & Citrus sinensis & $\begin{array}{l}\text { Astringent, Moisturizer, Scars, Acne, } \\
\text { Smoothness. }\end{array}$ & 7.0 \\
\hline 8 & Rosa, Santalum album & Anti-aging, Tone up the skin, Tighten the pores. & 8.0 \\
\hline 9 & Citrullus lanatus & Moisturizer, Refresher, Skin toner and tighter. & 9.0 \\
\hline 10 & Solanum xanthocarpum & Antiaging, Skin cleansing. & 10.0 \\
\hline 11 & Citrus limon & Skin nourishment, Cleansing and moisturizing. & 11.0 \\
\hline 12 & $\begin{array}{l}\text { Citrus sinensis, Carica papaya, Malus domestic, Prunus serotina, } \\
\text { Fragaria vesca, Citrus limon, Punicagranatum, Prunus persica. }\end{array}$ & Pimples, Antiaging, Skin cleansing, Softening. & 12.0 \\
\hline 13 & Citrus limon, Crocus stivus, Curcuma longa, Santalum album. & Depigmentation, Skin cleaning and fairness. & 13.0 \\
\hline 14 & Azadiractaindica & Antiaging, Skin softening. & 14.0 \\
\hline 15 & $\begin{array}{l}\text { Rosa, Prunus amygdalus, Crocus stivus, Citrus limon, Curcuma } \\
\text { longa, Santalum album. }\end{array}$ & Fairness, Softness & 15.0 \\
\hline 16 & $\begin{array}{l}\text { Embeliaribes, Rubiacordifolia, sidacordifolia, Acacia catechu, } \\
\text { Valerianajatamansi, Swarna gairik, Acorus calamus, } \\
\text { Psoraleacorylifolia, Aloe barbadensis, Curcuma longa, } \\
\text { Azadiractaindica, Santalum album. }\end{array}$ & Acne, Pimple and blemishes. & 16.0 \\
\hline 17 & $\begin{array}{l}\text { Eletteriacardamum, Valerianajatamansi, Glycyrrhiza glabra, } \\
\text { Vetiveriazizaniodes, Moringaoliefera, Cyperusscariosus, } \\
\text { samudraphen, Brassica compestris, Valerianawallichii, } \\
\text { Saussurealappa, Pavoniaodorata, Cinnamomumglaucescens, } \\
\text { Curcuma longa, Azadiractaindica, Santalum album. }\end{array}$ & Skin fairness and glowness. & 17.0 \\
\hline 18 & $\begin{array}{l}\text { SymplocosRacemosa, Punicagranatum, Mangiferaindica, } \\
\text { Azadiractaindica. }\end{array}$ & Fairness & 18.0 \\
\hline 19 & Curcuma longa, Santalum album. & Antifungal, Antiseptic. & 19.0 \\
\hline 20 & Aloe barbadensis & Anti-aging, dehydration of skin. & 20.0 \\
\hline 21 & $\begin{array}{l}\text { Citrus limon, Triticum stivum, Glycyrrhiza glabra, Calendula } \\
\text { officinalis, Aloe barbadensis, Curcuma longa, Azadiractaindica, } \\
\text { Santalum album. }\end{array}$ & $\begin{array}{l}\text { Detoxifying and nourishment of skin. Protect } \\
\text { from sunlight. }\end{array}$ & 21.0 \\
\hline 22 & Azadirachtaindica, Curcuma longa, Santalum album & Antifungal, Antiseptic. & 22.0 \\
\hline 23 & $\begin{array}{l}\text { Rubiacordifolia, sidacordifolia, Swarna gairik, Acorus calamus, } \\
\text { Psoraleacorylifolia, Aloe barbadensis, Curcuma longa, } \\
\text { Azadiractaindica, Santalum album, Rosa }\end{array}$ & & 23.0 \\
\hline 24 & Ocimum sanctum, Honey (saccharine liquid) & Antiseptic, Antifungal & 24.0 \\
\hline 25 & $\begin{array}{l}\text { Rosa, Prunus amygdalus, Crocus stivus, Citrus limon, Curcuma } \\
\text { longa, Santalum album. Crocus stivus }\end{array}$ & & 25.0 \\
\hline 26 & Rosa, Santalum album, Fragaria vesca, Carica papaya & Fairness, Softness & 26.0 \\
\hline 27 & Citrullus lanatus, Citrus limon & Antiseptic & 27.0 \\
\hline 28 & $\begin{array}{l}\text { Eletteriacardamum, Valerianajatamansi, Valerianawallichii, } \\
\text { Vetiveriazizaniodes, Glycyrrhiza glabra, Moringaoliefera, } \\
\text { Cyperusscariosus, samudraphen, Brassica compestris, Saussurealappa }\end{array}$ & Skin fairness and glowness & 28.0 \\
\hline 29 & Santalum album, Azadiractaindica & Antiseptic, Antifungal & 29.0 \\
\hline 30 & $\begin{array}{l}\text { SymplocosRacemosa, Punicagranatum, Mangiferaindica, } \\
\text { Azadiractaindica, Curcuma longa, Santalum album. }\end{array}$ & Fairness & 30.0 \\
\hline
\end{tabular}




\section{Reagents and Chemicals}

Nitric acid (SDFCL, Mumbai), Hydrochloride acid (SDFCL, Mumbai), Sulphuric acid (SDFCL, Mumbai), Hydrogen peroxide (Merck Millipore), Sodium borohydride (SigmaAldrich), Stannous chloride (Sigma-Aldrich). Water used in all experiments was ultrapure water from Milli-Q-water purification system. The standard solutions were prepared in five different concentrations to obtained calibration curve by diluting stock solutions of $1000 \mathrm{ppm}$ of each element. ${ }^{4-6}$

\section{Sample preparation:}

$10 \mathrm{~mL}$ of nitric acid was added to $2 \mathrm{~g}$ of accurately weighed dried sample in a $100 \mathrm{~mL}$ beaker and was heated on a hot plate at $95^{\circ} \mathrm{C}$ for 15 min to digest by wet digestion method. The digest sample was cooled and added $5 \mathrm{~mL}$ of concentrated nitric acid and heated for another $30 \mathrm{~min}$ at $95^{\circ} \mathrm{C}$. The heating steps were repeated until reduced to $5 \mathrm{~mL}$. The sample was again cooled and added $2 \mathrm{~mL}$ of deionized water and $3 \mathrm{ml}$ of $30 \%$ hydrogen peroxide. Close the beaker and sample was heated gently to start the peroxide reaction.
Sample was removed from the hot plate if effervescence becomes excessively vigorous. Further 30\% hydrogen peroxide was added in $1 \mathrm{ml}$ increments, followed by gentle heating until the effervescence was subsides. $5 \mathrm{ml}$ of concentrated hydrochloric acid and $10 \mathrm{ml}$ of deionized water was added and the sample was heated for another $15 \mathrm{~min}$ without boiling. The sample was cooled and filtered through a Whatman No. 42 filter paper and diluted to $50 \mathrm{ml}$ with deionized water. ${ }^{7-9}$

\section{Sample analysis:}

Prepared samples were analyzed forCd, $\mathrm{Pb}, \mathrm{Cu}, \mathrm{Al}, \mathrm{Zn}, \mathrm{Ca}$ and $\mathrm{Mg}$ byusing flame atomic absorption spectrophotometer and for $\mathrm{As}, \mathrm{Hg}$ using hydride generation technique. $\mathrm{Hg}$ was analyzed by cold vapor atomic absorption spectrometry. The $1000 \mathrm{ppm}$ standard solutions of elements were diluted in 5 different concentrations to obtain calibration curve. All the measurements were run in triplicate for the samples and standard solutions for to obtain the robust value. The instrumental conditions during the analysis of trace and heavy metals are listed in table-2.

Table No. 02: Instrumental condition for Analysis:

\begin{tabular}{|c|c|c|c|c|c|c|}
\hline Element Names & Current $(\mathbf{m A})$ & Slit width $(\mathbf{n m})$ & $\lambda_{\max }(\mathbf{n m})$ & Flame Colour & Flame type & AAS Performance \\
\hline $\mathbf{C a}$ & 3.5 & 0.5 & 422.5 & Orange & Air/Acetylene & Flame \\
\hline $\mathbf{M g}$ & 3.5 & 0.5 & 285.0 & Orange & Air/Acetylene & Flame \\
\hline $\mathbf{C u}$ & 5.0 & 0.5 & 325.0 & Blue & Air/Acetylene & Flame \\
\hline $\mathbf{Z n}$ & 5.0 & 1.0 & 214.0 & Blue & Air/Acetylene & Flame \\
\hline $\mathbf{A l}$ & 10.0 & 0.5 & 310.0 & Red & $\begin{array}{c}\text { Air/Acetyle/Di- } \\
\text { Nitrogen } \\
\text { Monoxide }\end{array}$ & Flame \\
\hline $\mathbf{C d}$ & 3.5 & 0.5 & 229.0 & Blue & Air/Acetylene & Flame \\
\hline $\mathbf{P b}$ & 10.0 & 1.0 & 217.2 & Blue & Air/Acetylene & Flame \\
\hline $\mathbf{A s}$ & EDL & 1.0 & 193.9 & Blue & Air/Acetylene & Hydride generation \\
\hline $\mathbf{H g}$ & EDL & 5.0 & 253.8 & - & - & Cold vapour \\
\hline
\end{tabular}

\section{Recovery studies:}

The accuracy of the method was performed as per ICH guideline by standard addition method at 3 different levels to demonstrate the validity of our method. A known amount of standard solutions containing $\mathrm{As}, \mathrm{Hg}, \mathrm{Cd}, \mathrm{Pb}, \mathrm{Cu}, \mathrm{Al}, \mathrm{Zn}, \mathrm{Ca}$ and $\mathrm{Mg}$ were prepared and spiked with digested samples, after dilution of sample to $50 \mathrm{ml} .{ }^{10}$

\section{RESULTS AND DISCUSSION}

The contents of trace elements are described in table- 3 in the screened preparations as a mean of triplicate determination. The calcium concentrations varied from 153 to $16600 \mathrm{ppm}, 8$ samples having contents between 2520 and 5991ppm. Sample 3 had the lowest calcium concentration and sample 16 had the highest. Calcium was also found below detectable limit in total seven samples. The copper concentrations varied from 2.7 to $50.1 \mathrm{ppm}$, most samples having contents between 9.2 and $23.1 \mathrm{ppm}$. Sample 20 had the lowest copper concentration and Sample 4 had the highest. The concentrations of copper were comparable in sample 6 and 7 with a range of 21.4-21.5, in 8 and 9 with a range of 20.221.2. ${ }^{11}$ The magnesium concentrations varied from 110 to $10.599 \mathrm{ppm}, 12$ samples having contents between 4601 and 8370ppm while three samples, 19, 20, and 21 had the equal magnesium concentration 110ppm. Sample 9 had the highest magnesium concentration. The zinc concentrations varied from 4.9 to $57.23 \mathrm{ppm}$, most samples having contents between 30.2 and $57.23 \mathrm{ppm}$. Sample 20 had the lowest zinc concentration and sample 12 had the highest. The concentrations of zinc were comparable in sample 8 and 10 with a range of 51.50 and 51.01 the same being true for sample code 18 and 11 at 47 and 47.05. The aluminum concentrations level ranged from 130 to $5525 \mathrm{ppm}$, most samples having contents between 3891 and 5525ppm. Sample 1 had the lowest aluminum concentration and sample 4 had the highest. ${ }^{12-14}$ 
Table No. 03: Metal content in herbal preparations:

\begin{tabular}{|c|c|c|c|c|c|}
\hline Sample ID & Ca $($ Mean \pm SD $)$ & $\mathrm{Cu}($ Mean \pm SD $)$ & $\operatorname{Mg}($ Mean \pm SD $)$ & $\mathrm{Zn}($ Mean \pm SD $)$ & $\mathrm{Al}($ Mean $\pm \mathrm{SD})$ \\
\hline 1.0 & $2520 \pm 51.38$ & $9.2 \pm 0.4$ & $2899 \pm 95$ & $52.03 \pm 0.30$ & $130 \pm 4.94$ \\
\hline 2.0 & $5991 \pm 263.32$ & $10.6 \pm 0.4$ & $5118 \pm 87$ & $51.97 \pm 0.38$ & $4913 \pm 38.83$ \\
\hline 3.0 & $153 \pm 11.50$ & $10.0 \pm 1.0$ & $6285 \pm 51$ & $50.12 \pm 0.40$ & $5123 \pm 38.30$ \\
\hline 4.0 & BDL & $50.1 \pm 0.6$ & $7381 \pm 69$ & $52.10 \pm 0.37$ & $5525 \pm 28.62$ \\
\hline 5.0 & $790 \pm 223.00$ & $49.0 \pm 0.1$ & $6700 \pm 691.2$ & $50.00 \pm 0.22$ & $5159 \pm 35.70$ \\
\hline 6.0 & $\mathrm{BDL}$ & $21.4 \pm 0.22$ & $4601 \pm 31.56$ & $34.52 \pm 7.23$ & $3891 \pm 80.46$ \\
\hline 7.0 & $190 \pm 112.52$ & $21.5 \pm 0.8$ & $5155 \pm 160.91$ & $40.01 \pm 0.25$ & $4492 \pm 37.89$ \\
\hline 8.0 & $3177 \pm 310.22$ & $20.2 \pm 0.56$ & $4910 \pm 93.96$ & $51.50 \pm 3.01$ & $4501 \pm 90.00$ \\
\hline 9.0 & $3696 \pm 310.35$ & $21.2 \pm 0.42$ & $10599 \pm 800$ & $53.22 \pm 0.34$ & $5002.1 \pm 108.14$ \\
\hline 10.0 & BDL & $23.2 \pm 0.7$ & $8212 \pm 473.01$ & $51.01 \pm 0.61$ & $4289 \pm 37.84$ \\
\hline 11.0 & $\mathrm{BDL}$ & $20.5 \pm 0.5$ & $8370 \pm 311.25$ & $47.05 \pm 0.43$ & $4845 \pm 78.11$ \\
\hline 12.0 & $3722 \pm 200.11$ & $23.1 \pm 0.9$ & $7959 \pm 200.23$ & $57.23 \pm 0.60$ & $5436 \pm 67.11$ \\
\hline 13.0 & $4352 \pm 190.11$ & $20.12 \pm 0.45$ & $5498.67 \pm 100.3$ & $50.89 \pm 0.21$ & $4780 \pm 83.00$ \\
\hline 14.0 & $1506.2 \pm 114.22$ & $23.01 \pm 0.6$ & $8300 \pm 75.0$ & $50.69 \pm 0.43$ & $575 \pm 15.86$ \\
\hline 15.0 & $12264 \pm 53.08$ & $22.9 \pm 0.29$ & $480 \pm 35.36$ & $19.02 \pm 0.63$ & $311 \pm 30.22$ \\
\hline 16.0 & $16600 \pm 452.4$ & $21.22 \pm 0.7$ & $2103 \pm 545.31$ & $20.29 \pm 0.55$ & $1131 \pm 79.06$ \\
\hline 17.0 & $4200 \pm 305.23$ & $20.1 \pm 0.67$ & $1372 \pm 15.96$ & $30.2 \pm 0.36$ & $808 \pm 92.45$ \\
\hline 18.0 & $4302 \pm 270.11$ & $17.1 \pm 0.5$ & $3510 \pm 114.33$ & $47.0 \pm 0.15$ & $3792 \pm 96.11$ \\
\hline 19.0 & BDL & $15.1 \pm 2.41$ & $110 \pm 0.63$ & $6.77 \pm 0.12$ & $324 \pm 72.96$ \\
\hline 20.0 & $\mathrm{BDL}$ & $2.7 \pm 0.69$ & $110 \pm 0.56$ & $4.9 \pm 0.22$ & $277 \pm 53.29$ \\
\hline 21.0 & $\mathrm{BDL}$ & $4.5 \pm 0.2$ & $114 \pm 0.32$ & $6.9 \pm 0.53$ & $229.55 \pm 20.05$ \\
\hline 22.0 & $190 \pm 114.02$ & $21.0 \pm 0.65$ & $5150 \pm 159.23$ & $39.01 \pm 0.50$ & $4452 \pm 51.39$ \\
\hline 23.0 & $1501 \pm 116.02$ & $23.0 \pm 0.5$ & $8300 \pm 80.2$ & $50.20 \pm 0.03$ & $580.1 \pm 1.02$ \\
\hline 24.0 & $2599 \pm 51.55$ & $9.0 \pm 0.5$ & $2970 \pm 92.5$ & $51.66 \pm 0.55$ & $125.6 \pm 8.23$ \\
\hline 25.0 & $791.3 \pm 241.11$ & $47.69 \pm 0.7$ & $6977 \pm 703.56$ & $51.26 \pm 0.22$ & $5196 \pm 38.03$ \\
\hline 26.0 & $16600 \pm 466.1$ & $21.0 \pm 0.6$ & $2088 \pm 570.2$ & $20.91 \pm 0.34$ & $1100 \pm 89.20$ \\
\hline 27.0 & $4220 \pm 310.11$ & $19.9 \pm 0.5$ & $1360 \pm 12.65$ & $32.04 \pm 0.12$ & $810.63 \pm 91.37$ \\
\hline 28.0 & $3210 \pm 310.22$ & $22.0 \pm 0.5$ & $4930 \pm 98.2$ & $52.46 \pm 4.53$ & $4522 \pm 90.22$ \\
\hline 29.0 & $151.00 \pm 11.03$ & $10.10 \pm 0.96$ & $6280 \pm 22.2$ & $48.88 \pm 0.42$ & $5231 \pm 49.02$ \\
\hline 30.0 & $2623 \pm 51.11$ & $9.6 \pm 0.2$ & $2967 \pm 87.23$ & $50.27 \pm 0.20$ & $125 \pm 6.11$ \\
\hline
\end{tabular}

Among the heavy metals, data presented in table-4 reveals that the mercury concentrations varied from 0.042 to 2.181 ppm, most samples having contents between 0.042 and 0.310 ppm. Sample 5 had the lowest mercury concentration and sample 18 had the highest. But mercury was found below detectable limit in eight samples. The concentrations of mercury were comparable in samples 11 and 21 with a range of $0.073-0.076 \mathrm{ppm}$. According to the WHO, the permissible limit for mercury in herbal preparations is $1 \mathrm{ppm}$. In that way, two samples $9(1.096 \mathrm{ppm})$ and $18(2.181 \mathrm{ppm})$ were found to contain mercury concentration above permissible limit. The arsenic concentrations varied from 0.681 to $3.682 \mathrm{ppm}$, most samples having contents between 1.32 and $3.68 \mathrm{ppm}$. Sample 1had the lowest arsenic concentration and 16 had the highest. According to the WHO, the permissible limit for arsenic in herbal preparations is $10 \mathrm{ppm}$. All the herbal cosmetic products under investigation accumulated this metal at a level appreciably below the permissible limit. The cadmium concentrations varied from 0.624 to $1.784 \mathrm{ppm}$, most samples having contents between 0.624 and 1.10ppm. Sample 21 had the lowest cadmium concentration and sample 24 had the highest. According to the WHO, the permissible limit for cadmium is $0.3 \mathrm{ppm}$ in herbal preparations and unfortunately, all the herbal cosmetic products were found to contain cadmium concentration higher than the permissible limit. The lead concentrations level ranged from 1.468 to 33.10 ppm. Sample 4 had the lowest lead concentration and sample 21 had the highest. But lead was found below detectable limit in four samples. According to the WHO, the permissible limit for lead is 10ppm. Six samples were contained $\mathrm{Pb}$ content above the permissible limit. The results of recovery study were within the acceptable range verifying the validity of proposed method for analysis (Table-5) and revealed that any small change in the drug concentration in the solution could be accurately determined by the proposed method. ${ }^{14-16}$

In the present study, herbal cosmetic products were found to contain variable amounts of trace (nutrient) elements. The variation in concentration of these elements may be mainly due to compositional differences of products and environmental condition where constituent plant is grown, use of fertilizer, pesticides. But generally, it is concluded that the studied products are rich source of essential elements $\mathrm{Mg}$, $\mathrm{Ca}, \mathrm{Zn}, \mathrm{Cu}$, and $\mathrm{Al}$ and hence might play an important role in the maintenance of the skin nutritional requirements ${ }^{11,12}$. 
Table No. 04: Metal content in herbal preparations:

\begin{tabular}{|c|c|c|c|c|}
\hline Sample ID & As $($ Mean \pm SD $)$ & Hg $($ Mean \pm SD $)$ & Cd $($ Mean \pm SD $)$ & $\mathrm{Pb}($ Mean $\pm \mathrm{SD})$ \\
\hline 1.0 & $0.681 \pm 0.022$ & BDL & $0.713 \pm 0.0009$ & $8.441 \pm 0.041$ \\
\hline 2.0 & $1.363 \pm 0.021$ & BDL & $0.789 \pm 0.200$ & $6.7430 \pm 2.080$ \\
\hline 3.0 & $1.466 \pm 0.024$ & $0.117 \pm 0.002$ & $1.234 \pm 0.112$ & $12.840 \pm 0.562$ \\
\hline 4.0 & $2.146 \pm 0.034$ & $0.167 \pm 0.002$ & $0.781 \pm 0.272$ & $1.468 \pm 0.849$ \\
\hline 5.0 & $1.841 \pm 0.029$ & $0.042 \pm 0.003$ & $0.890 \pm 0.249$ & $7.400 \pm 1.981$ \\
\hline 6.0 & $1.640 \pm 0.027$ & BDL & $0.990 \pm 0.319$ & $10.020 \pm 1.140$ \\
\hline 7.0 & $2.010 \pm 0.001$ & BDL & $0.784 \pm 0.110$ & $6.740 \pm 0.560$ \\
\hline 8.0 & $2.261 \pm 0.020$ & $0.310 \pm 0.010$ & $0.822 \pm 0.101$ & $11.300 \pm 1.900$ \\
\hline 9.0 & $2.920 \pm 0.050$ & $1.096 \pm 0.030$ & $0.859 \pm 0.340$ & $8.401 \pm 1.303$ \\
\hline 10.0 & $3.078 \pm 0.190$ & $0.066 \pm 0.011$ & $0.793 \pm 0.230$ & $6.432 \pm 1.966$ \\
\hline 11.0 & $2.638 \pm 0.041$ & $0.073 \pm 0.011$ & $0.725 \pm 0.170$ & $9.349 \pm 3.400$ \\
\hline 12.0 & $3.211 \pm 0.041$ & BDL & $0.750 \pm 0.162$ & $9.392 \pm 3.340$ \\
\hline 13.0 & $2.925 \pm 0.044$ & BDL & $1.252 \pm 0.552$ & $12.029 \pm 3.991$ \\
\hline 14.0 & $1.553 \pm 0.041$ & BDL & $1.784 \pm 0.483$ & $6.751 \pm 2.470$ \\
\hline 15.0 & $2.237 \pm 0.030$ & BDL & $1.092 \pm 0.250$ & BDL \\
\hline 16.0 & $3.682 \pm 0.180$ & $0.309 \pm 0.022$ & $1.157 \pm 0.236$ & $\mathrm{BDL}$ \\
\hline $\mathbf{1 7 . 0}$ & $2.923 \pm 0.051$ & $0.157 \pm 0.030$ & $0.692 \pm 0.114$ & BDL \\
\hline 18.0 & $3.420 \pm 0.046$ & $2.181 \pm 0.027$ & $0.993 \pm 0.311$ & BDL \\
\hline 19.0 & $1.887 \pm 0.020$ & $0.278 \pm 0.010$ & $0.625 \pm 0.057$ & $16.630 \pm 3.992$ \\
\hline 20.0 & $1.429 \pm 0.044$ & $0.083 \pm 0.015$ & $0.625 \pm 0.002$ & $20.580 \pm 3.750$ \\
\hline 21.0 & $1.563 \pm 0.039$ & $0.076 \pm 0.011$ & $0.624 \pm 0.001$ & $33.102 \pm 1.977$ \\
\hline 22.0 & $2.011 \pm 0.003$ & BDL & $0.784 \pm 0.121$ & $6.740 \pm 0.552$ \\
\hline 23.0 & $1.552 \pm 0.032$ & BDL & $1.784 \pm 0.522$ & $6.750 \pm 2.567$ \\
\hline 24.0 & $0.681 \pm 0.033$ & BDL & $0.712 \pm 0.00$ & $8.441 \pm 0.096$ \\
\hline 25.0 & $1.841 \pm 0.035$ & $0.042 \pm 0.004$ & $0.890 \pm 0.567$ & $7.400 \pm 1.723$ \\
\hline 26.0 & $3.681 \pm 0.171$ & $0.310 \pm 0.00$ & $1.156 \pm 0.034$ & $\mathrm{BDL}$ \\
\hline 27.0 & $2.924 \pm 0.020$ & BDL & $1.251 \pm 0.542$ & $12.000 \pm 3.795$ \\
\hline 28.0 & $2.260 \pm 0.020$ & $0.310 \pm 0.085$ & $0.821 \pm 0.106$ & $11.302 \pm 1.450$ \\
\hline 29.0 & $1.465 \pm 0.022$ & $0.117 \pm 0.000$ & $1.233 \pm 0.114$ & $12.830 \pm 0.422$ \\
\hline 30.0 & $0.680 \pm 0.029$ & $\mathrm{BDL}$ & $0.712 \pm 0.000$ & $8.439 \pm 0.059$ \\
\hline
\end{tabular}

Table 05: Recovery studies for trace elements and heavy metals:

\begin{tabular}{|l|l|l|l|l|}
\hline Metal & Base value (ppm) & Quantity added (ppm) & Quantity found (ppm) & Recovery \% \\
\hline $\mathbf{A l}$ & $125 \pm 7.79$ & 10.0 & 134.62 & 96.20 \\
\hline $\mathbf{C a}$ & $3647 \pm 63.42$ & 8.0 & 3655.22 & 98.62 \\
\hline $\mathbf{C u}$ & $4.36 \pm 0.16$ & 3.0 & 7.35 & 99.67 \\
\hline $\mathbf{M g}$ & $110.36 \pm 0.33$ & 1.0 & 111.36 & 99.99 \\
\hline $\mathbf{Z n}$ & $17.26 \pm 0.5$ & 2.0 & 19.22 & 98.00 \\
\hline $\mathbf{A s}$ & $2.949 \pm 0.041$ & 0.3 & 3.243 & 98.00 \\
\hline $\mathbf{H g}$ & $0.815 \pm 0.020$ & 0.2 & 1.013 & 99.00 \\
\hline $\mathbf{C d}$ & $0.671 \pm 0.44$ & 1.0 & 1.667 & 99.60 \\
\hline $\mathbf{P b}$ & $7.962 \pm 1.52$ & 5.0 & 12.961 & 99.98 \\
\hline
\end{tabular}

Toxic heavy metals $\mathrm{Pb}, \mathrm{Cd}$, As and $\mathrm{Hg}$ were detected in all the investigated cosmetic products. The cosmetic products related regulations do not decide maximum permissible limit values for heavy metals content in cosmetic products except of $1 \mathrm{ppm}$ for $\mathrm{Hg}$ (ACSB 2007). However, Cd is prohibited in any amount in cosmetics (Council Directive 76/768/EEC of 27 July 1976). The presence of heavy metals in cosmetics can cause serious problems to consumer as they can cause premature aging of the skin, skin allergies, and skin cancer. Further, toxic metals have a role to set up conditions that lead to inflammation in arteries and tissues, results in osteoporosis13. Thus, there is an urgent need for constant quality assessment of cosmetic products in the market in order to ensure the safety of consumers. To achieve this, regulatory bodies and the government sector should implement the stringent policies to regulate and monitor the standards of herbal products manufactured, advertized, sold, and used. At the same time, scientific community should develop simple and convenient analytical methods.

The most widely techniques to analyze trace and heavy metals are atomic absorption spectrometry (AAS), inductively coupled plasma mass spectrometry (ICP-MS), inductively coupled plasma atomic emission spectrometry (ICP-AES), and X-ray fluorescence spectroscopy (XFS) 14. However, the instrumental methods of ICP-MS, ICP-AES, and XFS are usually more costly, and their use is not as straightforward and convenient as AAS. In this study, a 
simple, reliable, sensitive and convenient AAS method has been developed for quantitative estimation of trace metals and heavy metals which can conveniently be utilized for the quality control of herbal cosmetic preparations at industrial level. ${ }^{16}$

\section{CONCLUSION}

30 herbal cosmetic preparations sold in Indian market found to figure out some biologically important trace elements, which may be helpful to impart therapeutic efficiencies unfortunately, these products were also contained toxic heavy metal content above the permissible limits which may cause deleterious effects to the human health. In the present scenario, there is an urgent need to regulate them properly for the sustainable safety and efficacy. ${ }^{3,8}$,

\section{REFERENCES}

1. Kapoor V.P. Herbal cosmetic for skin and hair care, Nat. Prod. Radiance. 2005;4(4):306-12

2. Goodman and Gillman, "Pharmacological Basis of Therapeutics", 6th Ed., 321

3. WHO. Environmental Health Criteria: International Programme on Chemical Safety. World Health Organization, Geneva.1995:165

4. Ernst E. Toxic heavy metals and undeclared drugs in Asian herbal medicines, Trends Pharmacol. Sc. 2002; 23:136-9

3. Sun H.W., Ying. G., Yuan. C.G., Zhang. Y.X., Lili. Y. and De-q. Z. Determination of trace lead in Chinese herbs by derivative flame atomic absorption spectrometry using an atom trapping technique. Anal. Sci. 2002; 18:325-28

4. Ayenimo J.G., Yusuf A.M., Adekunle A.S. and Makinde O.W. Heavy Metal Exposure from Personal Care Products, Bull. Environ. Contam. Toxicol.2010; 84:8-14

5. Sukender K., Jaspreet S., Sneha D. and Munish G AAS Estimation of Heavy metals and Trace Elements in Indian Herbal Cosmetic preparation. Res. J. Sci. 2012;2(3): 46-51

6. Health Canada, Draft guidance on heavy metal impurities in cosmetics, Section 4
7. Ajayi S.O., Oladipo M.O.A., Ogunsuyi H.O. and Adebayo A.O., Determination of the minor and trace elements in Biriniwa tin pyrite and ornamental lead/zinc ore using neutron activation analysis, Bull. Chem Soc. Ethiopia. 2002; 16(2):207-11

8. Nanorom I.C., Igwe T.C. and Oji-Nnorom C.G., Trace metal contents of facial (make-up) cosmetics commonly used in Nigeria, Afr. J. Biotechnol. 2005;4(10):1133-8

9. Nwoko C.O. and Mgbeahuruike L., Heavy metal contamination of ready-to-use herbal remedies in south eastern Nigeria, Pak. J. Nutr., 2011;10(10):959-64

10. Al-Omari S., Determination of essential and toxic trace elements in ten herbal medicines using energy-dispersive XRF analysis, X-Ray Spectrom. 2011; 40:31-6

11. Gomez M.R., Cerutti S., Somb L.L., Silva M.F. and Martınez L.D., Determination of heavy metals for the quality control in Argentinian herbal medicines by ETAAS and ICP-OES, Food and Chem. Toxicol. 2007; 45:1060-4

12. Ajasa A.M.O., Bellob M.O., Ibrahimb A.O., Ogunwandea I.A. and Olaworeb N.O., Heavy trace metals and macronutrients status in herbal plants of Nigeria, Food Chemistry. 2004; 85(1):67-71

13. Sharma D.K., Rai S., Arora S.S., Gupta P.M., Sharma R. and Chopra A.K. Study of the trace elements in Aloe veraL. (Aloe barbandensisMiller) viz. Liliaceae and its biological and environmental importance, J. Chem. Pharm. Res., 2011; 3(3):64

14. Farr G., The hair tissue mineral analysis/why heavy metals are a hazard to your health, Updated 31Dec. 2009.

15. Naithani V., Pathak N. and Chaudhary M. Evaluation of heavy metals in two major ingredients of Ampucare, Int. J. Pharm. Sc. Drug Res.,2010; 2(2):137-44

16. Baranowska, I., Srogi, K., Wlochowicz, A. Szczepanik, K. Determination of Heavy Metal contents in samples of Medi-cinal Herbs. Polish Journal of Environmental Studies, 2002;11(5):467-71

17. Barr. R. D., Woodger B.M. and Rees. P.H. Levels of mercury in urine correlated with the use of skin lightening creams. Am. J. Clin. Pathol.1973;59: 36-40

18. Noviana, E., D.P. Heri, Astuti, and A. Rohman. Validation of mercury analyzer for determination of mercury in snake fruit. Int. Food Res. J.2012; 19(3): 933-36

19. World Health Organization (2003). Traditional Medicine, Fact sheet No. 134 Vogel A.I. A text book of quantitative inorganic chemical analysis including elementary instrumental analysis. Logman Inc., London. 2001; 5th edition: 80. 